\title{
Vichy in Baden-Baden - The Personnel of the French Occupation in Germany after 1945
}

\author{
Julia Wambach ${ }^{*}$ \\ Max Planck Institute for Human Development, Center for the History of Emotions, Lentzeallee 94, 14195 Berlin, \\ Germany \\ *wambach@mpib-berlin.mpg.de
}

This article examines the contested presence of Vichy administrators in high positions of the French administration of occupied Germany after the Second World War. In occupied Germany, where many of Pétain's officials pursued their careers, resisters and collaborators negotiated their new positions in the wake of the German occupation of France. Key to understanding this settlement are the notions of expertise and merit as well as the role of the inherited French social order untouched by the collaboration.

'The French administration in Germany is full of survivors of Vichy', ran the headline of the French communist newspaper Ce Soir on 16 November $1945 .{ }^{1}$ Part of a longer reportage entitled 'The failure of Baden-Baden', this article was far from the only one that uncovered the peculiar situation of the personnel in the capital of the French occupation zone in Germany in autumn 1945. Indeed, all major left-wing newspapers in France were outraged by the surprisingly large number of former Vichy officials employed in French-occupied Germany: Combat, Le Monde, Front National, Temps Présent, Nouvelles de France, Ordre and Résistance all discussed the topic over the course of the first three weeks of November $1945 .{ }^{2}$ Most of the articles were travelogues by journalists who had visited the zone and informed their readers back home about the similarities between the two spa towns: Vichy, the capital of Marshal Pétain's collaborationist French State, and Baden-Baden, the capital of the French zone of occupation in Germany. ${ }^{3}$ The journalists picked up nicknames for the capital of the French zone circulating in the city itself and shared them with their readers in France. Hushed whispers called the city Vichy-Vichy or little Vichy, Baderne-Baderne (baderne meaning geezer) or Naphtalingrad (naphtaline meaning

For their precious feedback, I would like to thank the members of Berkeley's German working group Der Kreis and StefanLudwig Hoffmann (Berkeley), Olivier Wieviorka (Paris) and the working group National Socialism of Centre Marc Bloch (Berlin), as well as Sheer Ganor (Berkeley), Trevor Jackson (Berkeley), Hanne Leßau (Nuremberg), Melissa Turoff (New York City), Florian Wagner (Erfurt) and my two anonymous reviewers. For their help finding relevant archival collections, I am very grateful to Cyril Daydé of the archives of Ministère des Affaires Etrangères (La Courneuve) and Stéphane Launey of Service Historique de la Défense (Vincennes).

1 Jacques-Francis Rolland, 'La faillite de Baden-Baden. L'administration française en Allemagne est peuplée de rescapés de Vichy', Ce Soir, 16 Nov. 1945.

2 A collection of those newspaper articles is stored at Archives du Ministère des Affaires Etrangères La Courneuve (MAE), AC 852/10 Allemagne, guerre. 1944-6. F. Roy Willis, whose 1962 study The French in Germany 1945-1949 remains to this day the only comprehensive work on the French occupation of Germany after the Second World War, mentioned these newspaper articles and their criticism of the presence of Vichy administrators. See F. Roy Willis, The French in Germany 1945-1949 (Stanford University Press, 1962), 77-86.

3 Roger Stéphane, 'A Baden, Les Français divisent l'Allemagne et ignorent les Allemands', Combat, 19 Nov. 1947.

(c) Cambridge University Press 2018. 
mothballs). ${ }^{4}$ A journalist from Front National ${ }^{5}$ pushed the similarities between Vichy and BadenBaden even further and stated: 'all spa towns resemble each other. All provisional capitals too. Therefore, there is nothing more normal than to run across the same influential personages in the same very high positions' ${ }^{6}$ 'The French administration in Germany is the refuge of high government officials compromised under the Vichy regime, former prefects, survivors of the purge commissions, in which they were more or less whitewashed out of weakness or complicity', one could read in another article. ${ }^{7}$ The French should have sent their administrative and political elite to Germany, the journalists complained, because the French administration in occupied Germany was responsible for the denazification and democratisation of the Germans. Thus, part of the French public opinion was deeply sceptical that former Vichy officials were able to successfully govern the Germans.

This article analyses a much overlooked chapter of European history at the pivotal moment of change from the German occupation of France to the French occupation of Germany in the years 1944-5: the Vichy background of the personnel employed in the French occupation forces of Germany after the Second World War. It will address the ways in which the French wartime collaboration influenced the subsequent French post-war occupation of Germany, explore how Vichy administrators employed in Germany navigated this transition and investigate how the government and the public in post-war France confronted this legacy and its attendant ethical problems. In tracing the career paths of those French occupiers in Germany, notably back to the German wartime occupation of France, I will show the interconnectedness of the history of these two countries through their shared implication with Nazism and their struggle to rid themselves of this heritage.

'The old battle horse of the purge has crossed the Rhine as well', wrote Le Monde in an article about the Vichyssois ${ }^{8}$ in the French zone of occupation on 13 November 1945. ${ }^{9}$ The image used in this citation neatly sums up the argument developed here. The conflict, oftentimes called 'civil war,' between collaborators and resisters in liberated France over what was considered adequate conduct during the German occupation of France between 1940 and 1944 continued in the aftermath of the war, and throughout the French occupation of Germany between 1945 and 1955. ${ }^{10}$ Many of Pétain's officials were sent to Germany in what Martial Libera has called a

4 See Jacques-Francis Rolland, 'La faillite de Baden-Baden. L'administration française en Allemagne est peuplée de rescapés de Vichy', Ce Soir, 16 Nov. 1945; Paul Bodin '7.000 fonctionnaires auxquels on a donné uniformes et galons n'ont su ni épurer notre zone d'occupation ni y faire respecter la France', Combat, 13 Nov. 1945; Albert Palle, 'Loin de Baden-Baden', Combat, 5 Jan. 1946; Alexandre Astruc, 'L'Allemagne vue de la zone d'occupation française: Une façade qui s'ouvre sur le néant', Combat, 27 Jun. 1946.

5 A newspaper published by the communist resistance group Front national de lutte pour la libération et l'indépendance de la France, not to be confused with the right-wing party founded by Jean-Marie Le Pen.

6 'Pourquoi nous perdons la bataille de l'occupation. Le "Tout-Vichy" à Baden-Baden où un protégé de Darnand applique la justice', Front National, 15 Nov. 1945.

7 Jacques-Francis Rolland, 'La faillite de Baden-Baden. L'administration française en Allemagne est peuplée de rescapés de Vichy', Ce Soir, 16 Nov. 1945.

8 The official term for the Vichy supporters is vichystes while the inhabitants of the city of Vichy are called vichyssois. The newspaper articles, however, used the term Vichyssois to designate the former members of the Vichy administration, which is why I decided to keep the term.

9 'La vie à Baden-Baden', Le Monde, 13 Nov. 1945.

${ }^{10}$ Henry Rousso used the notion of 'civil war' when he described the coming to terms with collaboration and resistance in the aftermath of the Second World War in France in The Vichy Syndrome. History and Memory in France since 1944 (Harvard University Press, 1994). Olivier Wieviorka, however, contested the notion of a civil war between resisters and collaborators in France in his article 'Guerre civile à la française ? Le cas des années sombres (1940-1945)', Vingtième Siècle. Revue d'Histoire, 85,1 (2005), 5-19. Wieviorka argues that the French on both sides - resisters and collaborators successfully tried to avoid a civil war in France. I decided to keep the term 'civil war' because I want to underline the conflict around the coming to terms with resistance and collaboration and the spectre of violence and civil war during the shift of power in 1944-5, which is why the Vichyssois found themselves in Germany after the Second World War. At the same time, I acknowledge Wieviorka's point and put 'civil war' in inverted commas. One could also speak of a 'cold civil war'. 
'policy of removal' (politique d'éloignement) where they could hide from persecution or degradation in France, and where they pursued their careers. ${ }^{11}$ Their presence in occupied Germany illustrates how these tainted bureaucrats bridged their professional gap between Vichy France and their careers in the French Fourth Republic by offering their expert knowledge in matters of administration to serve the new post-war regime - making up for their 'misconduct' in Vichy France. For the former Vichy officials, serving in Germany was thus a moral cleansing process, a hibernation period they had to go through before they were allowed back into metropolitan France. In occupied Germany, French resisters and collaborators were forced to work together for the 'new France'. Occupied Germany thus serves as case study of the mechanisms for the settlement of the conflict between resisters and collaborators. Key to understanding this settlement are the notions of expertise and merit as well as the role of the inherited French social order untouched by the collaboration. As a side effect, the French experience with their own purges and the presence of the former Vichy administrators in their own ranks led to a similar approach to (and failure of) denazifying the Germans. Therefore, the oft-cited success story of reconciliation between France and Germany has also a rather dark side: the presence of Vichy administrators in the French zone who wanted to make their own past forgotten. This article is about their transition from Vichy to the Fourth Republic.

\section{The Vichy Administration}

The victory of Nazi Germany against France in June 1940 divided the French into two camps: a minority who wanted to continue to fight the Germans and thus mainly went into exile, and the majority who accepted the defeat and used the moment to rebuild the state. The latter group considered the Third Republic terminally ill owing to its endless parliamentary debates and divisions, at least since the failure of the Popular Front in the late 1930s, and consequently called for a conservative national revolution under the new head of state, Marshal Pétain. The Vichy regime, a semi-independent state that worked together with the Nazi occupiers, but had its own political agenda, was unique in occupied Europe. ${ }^{12}$ Whoever worked for this Vichy state, complied with its ideas or actively sought out contact with the German occupier between 1940 and 1944, later became suspect of 'collaboration' after the liberation - especially in the eyes of those who 'resisted' the Germans and doubted the legitimacy of the Vichy government.

The administrative apparatus was both the heart and (long) arm of the Vichy state and its personnel were very visible to all French citizens. It is for this reason that, in the autumn of 1945, the left-wing French press turned against those Vichyssois in Germany who had been in the most prestigious administrative positions of the Vichy state, notably Vichy prefects or members of Pétain's ministries in occupied France. In 1945 journalists unveiled a number of names of former Vichy government officials employed in the French occupation administration in Germany. The communist newspaper Ce Soir wrote:

Next to the administrator general, the courageous resister Monsieur Laffon, it is surprising to find men whose attachment to the democratic cause seems questionable. The director general of administrative affairs and second in the hierarchy is Monsieur Sabatier. Monsieur Sabatier

\footnotetext{
11 See Martial Libera, Un rêve de puissance: la France et le contrôle de l'économie allemande (1942-1949) (Bruxelles: Peter Lang, 2012), 312.

12 The literature on occupied France is overwhelming. For a short overview see Fabian Lemmes, 'Collaboration in Wartime France, 1940-1944', European Review of History - Revue européenne d'histoire, 15, 2 (2008), 157-77. For a more detailed overview see: Julian Jackson, France: The Dark Years, 1940-1944 (Oxford: Oxford University Press, 2001); Philippe Burrin, La France à l'heure allemande (1940-1944) (Paris: Seuil, 2015) and Robert Gildea, Marianne in Chains (London: Pan Macmillan, 2011). For an overview of the prefectural staff during Vichy, see Marc Olivier Baruch's article 'Qui sont les préfets de Vichy?' on the Institut d'histoire du temps présent's website: http://www.ihtp.cnrs.fr/prefets/de/content/quisont-les-pr\%C3\%A9fets-de-vichy (last visited 10 July 2018).
} 
was the regional prefect of Bordeaux. I think it is pointless to explain to the French people what a regional prefect under Vichy was!

The assistant general director is Monsieur Périer de Féral. Monsieur Périer de Féral was secretary general of the Seine department. His attitude during the occupation resulted in his suspension and three months imprisonment after the Liberation.

Monsieur Filippi, the director of the economy and finance department, organised the finances of Vichy together with Monsieur Bouthillier. ... ${ }^{13}$

The director of the personnel is Monsieur Lacomb[e], ${ }^{14}$ one of the most dynamic prefects of Vichy. ${ }^{15}$

These Vichy administrators were, however, not among top tier Vichy administrators. After the war, the leading Vichy ministers, who in part had found refuge between September 1944 and April 1945 in another idyllic German town, Sigmaringen, only ninety miles southeast of BadenBaden, had been tried and sent to prison. In the case of the ministers of the interior, they had even received death penalties. ${ }^{16}$ Thus, the Vichy administrators who went to occupied Germany after the war were either second- or third-rank technocrats in the ministries, or had held positions in municipalities rather than in the main control centres of decision making.

At the liberation all Vichy prefects were immediately suspended. The ministry of the interior convened a purge commission following the decree of 27 June 1944 concerning the purge of the administration within the territory of metropolitan France. ${ }^{17}$ But the purge commission did not send the Vichy prefects to prison. It even whitewashed and reintegrated many of them into the prefectural staff. Admittedly, the purge commission did not have an easy job establishing 'the truth' about the life and behaviour of the Vichy officials due to both contradictory testimonies and insufficient documentation. For example, in the case of the regional prefect of Bordeaux, Maurice Sabatier, the commission did not ask about his role in the deportation of Jews, a question only raised much later: 'it seemed as if he did not have French blood in France on his hands', recalled one of his future colleagues in Baden-Baden. ${ }^{18}$

Most of the administrators had spent a long period of time in various prefectures or ministries, governments and task forces, which made them experienced organisers and technicians of a variety of functions within an administration. Rather than Vichy ideologues, these men were seen

13 Minister of Finance under Vichy and supporter of Pétain's conservative revolution.

14 Interestingly, many journalists misspelled the names of the Vichyssois, which is a sign for the orally transmitted information they picked up in Germany.

15 Jacques-Francis Rolland, 'La faillite de Baden-Baden. L'administration française en Allemagne est peuplée de rescapés de Vichy', Ce Soir, 16 Nov. 1945.

16 For the purges in France, see the classic Peter Novick, The Resistance versus Vichy: The Purge of Collaborators in Liberated France (London: Chatto \& Windus, 1968) and a more recent work: Jean-Paul Cointet, Expier Vichy: l'épuration en France (1943-1958) (Paris: Perrin, 2008) as well as a study focused on the purges of the French administration: François Rouquet, Une épuration ordinaire (1944-1949): Petits et grands collaborateurs de l'administration française (Paris: CNRS éditions, 2011). The context of those legal purges constituted the 'wild purges': Fabrice Virgili, Shorn Women: Gender and Punishment in Liberation France (London: Berg Publishers, 2002) and Philippe Bourdrel, L'épuration sauvage (19441945) (Paris: Perrin, 1991). The research on the purges in France does often not focus on the period between the purges and the reappearance and reintegration of the purged into the society. For the literature on the Vichy government's last refuge in Sigmaringen, see: Henry Rousso, Un château en Allemagne: Sigmaringen, 1944-1945 (Paris: Pluriel, 2012) (first published as Un château en Allemagne: La France de Pétain en exil, Sigmaringen 1944-1945 (Paris: Ramsay, 1980)); JeanPaul Cointet, Sigmaringen. Une France en Allemagne (Septembre 1944-Avril 1945) (Paris: Perrin, 2003). Also, see for a literary account of the Vichy government in Sigmaringen, Louis-Ferdinand Celine's famous Castle to Castle (New York City: Delacorte, 1968) (Louis-Ferdinand Céline, D’un château l'autre (Paris: Gallimard, 1958).

17 Archives Nationales Pierrefitte sur Seine (AN) F1bI 932 Commission d'épuration du Ministère de l'Intérieur Documentation. Letter from the president of the purge commission to the Minister of the Interior about the history of the purge commission, 15 Feb. 1946. Also, see Marc Olivier Baruch, 'L'épuration du corps préfectoral', in Marc Olivier Baruch, ed., Une poignée de misérables. L'épuration de la société française après la Seconde Guerre Mondiale (Paris: Fayard, 2003), 139-71.

18 Service Historique de la Défense (SHD), Archives orales, 3 K 49, Bolotte. Entretien 2, plage 12. Bolotte did this interview in 1999 after Maurice Papon, Sabatier's immediate subordinate, was tried for his complicity in crimes against humanity. 
as technocrats whose expertise and knowledge were the main consideration when deciding on their employment in and transfer to Germany. One of the reports about the former Vichy prefects in the French zone of occupation, for example, explicitly underlined that the prefect is not an improvised civil servant of the Vichy government, but belonging well to the permanent cadre of the ministry of the interior. ${ }^{19}$ Their prefectural status made them one of the highest ranked and most prestigious civil servants of the French state. ${ }^{20}$

However, they were still a visible representation of the Vichy regime as prefects or subprefects in their own department and within their own populations. One of the prefects, Jean Cabouat, who had a Jewish wife and a son who had joined the resistance and got into trouble with the French collaborationist militia in his department, was chosen by the resistance to become one of the first prefects of the liberation. However, he had to resign as early as the winter of 1944 because the population in his department (Pas-de-Calais) refused to accept a former Vichy prefect and requested, as one representative from Pas-de-Calais put it, 'a prefect who resisted a little more. ${ }^{21}$ Therefore, the prefects could not be easily reinstated in metropolitan France. To solve the problem of those fallen prefects, the ministry of the interior sent the former Vichy administrators outside of the metropole - invisible to the French population's eyes - as a way to avoid trouble. Two of the above-cited newspaper articles from autumn 1945 blame Minister of the Interior Adrien Tixier's for this practice. One of them even quoted Tixier verbatim: 'I send to Germany all those who bother me in Paris'. ${ }^{22}$

\section{To Germany}

The Military Mission for German Affairs (Mission Militaire pour les Affaires Allemandes; MMAA) was responsible for the recruitment of personnel for the French occupation zone, but it had particular difficulties finding suitable personnel and coordinating several institutions involved in developing French policies for occupied Germany. ${ }^{23}$ The MMAA itself was headed by General Louis Koeltz, who had been appointed to this position by Charles de Gaulle in November of 1944. Koeltz was a military officer, experienced in German affairs since the First World War. After the French defeat in 1940 - and this is what the journalists in the fall 1945 criticised in particular - he continued to serve in leading positions in the French Vichy army. He was a member of the armistice commission in Wiesbaden and subsequently fought in the Middle East and North Africa - on the Vichy side, it should be added. Front National wrote that he 'distinguished himself in Syria, then in North Africa, where he gave orders to the French troops to open fire on the landing American troops'. ${ }^{24}$ Because of these orders, the Americans briefly imprisoned Koeltz in Algiers, as another article underlined. ${ }^{25}$ In the post-war period Koeltz became the French permanent representative on the Allied Control Council in Berlin. It was he

19 MAE 1 PL 2459 A 2460 Lacombe, Jean. Intelligence note on Jean Lacombe, no date.

20 There were only 275 prefects in Vichy France. See Jean-Paul Cointet, Expier Vichy: l'épuration en France (1943-1958) (Paris: Perrin, 2008), 336. Because they were considered the long arm of the government, the new governments in France in 1848 and 1871 had removed all prefects of the previous regimes, see Robert Paxton, Vichy France: Old Guard and New Order 1940-1944 (Columbia University Press, 2001), 341-2.

21 AN F1bI 1127 Cabouat, Jean. André Blumel to Minister of the Interior, Affaire Cabouat, 4 Nov. 1944.

22 'Pourquoi nous perdons la bataille de l'occupation. Le “Tout-Vichy” à Baden-Baden où un protégé de Darnand applique la justice', Front National, 15 Nov. 1945. See also Jacques-Francis Rolland, 'La faillite de Baden-Baden. L'administration française en Allemagne est peuplée de rescapés de Vichy', Ce Soir, 16 Nov. 1945.

23 See Martial Libera, Un rêve de puissance: la France et le contrôle de l'économie allemande (1942-1949) (Bruxelles: Peter Lang, 2012), 299-300 and Dietmar Hüser, Frankreichs 'doppelte Deutschlandpolitik': Dynamik aus der Defensive - Planen, Entscheiden, Umsetzen in Gesellschaftlichen und Wirtschaftlichen, Innen- und Aussenpolitischen Krisenzeiten: 1944-1950 (Berlin: Duncker \& Humblot, 1996), 117.

24 J.-P. Penez, 'Le “Tout-Vichy” à Baden-Baden où un protégé de Darnand applique la justice', Front National, 15 Nov. 1945. 
who appointed many former Vichy officials to their positions in the French zone, as one article confirmed: 'those who were too "burnt" [during the Vichy regime] were pushed through with the help of General Koeltz, organiser of the executives in Germany'. ${ }^{26}$

The recruitment of personnel by Koeltz's MMAA was slow to get started. In March 1945, when the French army had already crossed the Rhine, only 300 French officers had been recruited to govern the occupied territory. ${ }^{27}$ Personnel were not easy to find because the ministries in Paris wanted to keep their best administrators for the rebuilding of metropolitan France and not for the occupation of Germany. ${ }^{28}$ Recruitment was done hastily, and some members of the occupying administration were therefore employed without a thorough background check. ${ }^{29}$ Emile Laffon, head of the civilian government of the French zone (confusingly called gouvernement militaire, military government) complained in a secret personal report to General Koenig, French commander-in-chief in Germany, in September 1945 about the MMAA's recruitment policies, highlighting the 'hurried ... choices without a serious control' ${ }^{30}$ Laffon also criticised the MMAA's recruitment from the bottom-up, leaving the choice of the heads of departments for the government who then had to decide at the very last minute about the personnel for the important positions in the administration of the French zone. ${ }^{31}$

The multitude of institutions in Paris and Baden-Baden involved with the occupation added to the complexity of decision making, leaving room for loopholes and informal arrangements on the choice of the personnel for Germany. ${ }^{32}$ The MMAA, as well as its successor organisation,

25 Jacques-Francis Rolland, 'La faillite de Baden-Baden. L'administration française en Allemagne est peuplée de rescapés de Vichy', Ce Soir, 16 Nov. 1945.

26 Jacques-Francis Rolland, 'La faillite de Baden-Baden. L'administration française en Allemagne est peuplée de rescapés de Vichy', Ce Soir, 16 Nov. 1945.

27 Dietmar Hüser, Frankreichs 'doppelte Deutschlandpolitik': Dynamik aus der Defensive - Planen, Entscheiden, Umsetzen in Gesellschaftlichen und Wirtschaftlichen, Innen- und Aussenpolitischen Krisenzeiten: 1944-1950 (Berlin: Duncker \& Humblot, 1996), 117.

28 Archives Sciences Po Paris. Fonds Grimaud. GRI 4. Dossier 1. Occupation en Allemagne 1945-1947. 2ème dossier: Problèmes et polémiques. Documents administratifs 1945-1947. Rapport de l'Administrateur Général Adjoint pour le Gouvernement Militaire de la Zone Française d'Occupation to Monsieur le Général de Corps d'Armée Commandant en Chef Français en Allemagne, Baden-Baden, 17 Sept. 1945, 2. See for France's focus on the reconstruction of France and domestic policies in the aftermath of the war: Dietmar Hüser, Frankreichs, doppelte Deutschlandpolitik': Dynamik aus der Defensive - Planen, Entscheiden, Umsetzen in Gesellschaftlichen und Wirtschaftlichen, Innen- und Aussenpolitischen Krisenzeiten: 1944-1950 (Berlin: Duncker \& Humblot, 1996).

29 There were, for instance, secretaries who could not do shorthand, Laffon complained, or drivers unable to drive. While this article focuses on the high government officials that had been employed in the Vichy regime and in occupied Germany and could stay in Germany because of their expertise in matters of administration, it is important to note that this was just the tip of the iceberg of tainted French employees in occupied Germany. Laffon stated that in the fall of 1945 he had already sent back to France around forty officers who were incompetent or whose performance had been considered inadmissible'. See Archives Sciences Po Paris. Fonds Grimaud. GRI 4. Dossier 1. Occupation en Allemagne 1945-1947. 2ème dossier: Problèmes et polémiques. Documents administratifs 1945-1947. Rapport de l'Administrateur Général Adjoint pour le Gouvernement Militaire de la Zone Française d'Occupation to Monsieur le Général de Corps d'Armée Commandant en Chef Français en Allemagne, Baden-Baden, 17 Sept. 1945, 2-3.

30 Archives Sciences Po Paris. Fonds Grimaud. GRI 4. Dossier 1. Occupation en Allemagne 1945-1947. 2ème dossier: Problèmes et polémiques. Documents administratifs 1945-1947. Rapport de l'Administrateur Général Adjoint pour le Gouvernement Militaire de la Zone Française d'Occupation to Monsieur le Général de Corps d'Armée Commandant en Chef Français en Allemagne, Baden-Baden, 17 Sept. 1945, 2.

31 Archives Sciences Po Paris. Fonds Grimaud. GRI 4. Dossier 1. Occupation en Allemagne 1945-1947. 2ème dossier: Problèmes et polémiques. Documents administratifs 1945-1947. Rapport de l'Administrateur Général Adjoint pour le Gouvernement Militaire de la Zone Française d'Occupation to Monsieur le Général de Corps d'Armée Commandant en Chef Français en Allemagne, Baden-Baden, 17 Sept. 1945, 2.

32 The historiography on the French occupation in Germany has underlined that the veritable patchwork of the French administration had also positive effects. See Alain Lattard, 'Zielkonflikte französischer Besatzungspolitik in Deutschland. Der Streit Laffon-Koenig 1945-1947’, Vierteljahrshefte für Zeitgeschichte (1991), 4. The administrative patchwork left room for initiatives with regard to the French social policies, the culture or the creation of unions. See, for instance, Rainer Hudemann, Sozialpolitik im Deutschen Südwesten zwischen Tradition und Neuordnung, 1945-1953: Sozialversicherung 
the Interministerial Committee for German and Austrian Affairs (Comité Interministériel des Affaires Allemandes et Autrichiennes; CIAAA), founded in July 1945), had difficulties asserting itself as a control centre and mediator between the different ministries in Paris (each of which had their own department of German Affairs - and interests) and the nascent French occupation administration in Germany. The latter had its own conflicts, notably the quarrel about administrative responsibilities in the zone between its two main bodies - the military under General Koenig, and the civilian government headed by Emile Laffon. ${ }^{33}$ This exacerbated the problem of chaotic recruitment and thus some administrators obtained their positions through informal networks in Paris and Baden-Baden. Therefore, the Minister of the Interior, Tixier, could take advantage of the existing chaos to accomplish his goal of sending all those to Germany who bothered him in Paris. ${ }^{34}$

Even members of the resistance hired former Vichy administrators. As future head of the civilian administration of the French zone in Germany, Emile Laffon had an important task in choosing his staff. In contrast to General Koeltz of the MMAA, Laffon was a civilian and from the resistance. He was a trained mining engineer, had joined the resistance in 1942 and had become a member of the department of the interior of the French provisional government in London. He was appointed general director of the ministry of the interior in 1944. In this position, Laffon came to know all of the former prefects and could pick and choose his colleagues for occupying Germany. ${ }^{35}$ While he gathered a group of younger administrators from the resistance around him, he also installed the former Vichy prefect Jean Cabouat as head of security in the French zone. ${ }^{36}$ Finally, the governors of the occupation zone themselves also chose their own staff. For instance, Governor Grandval of the Saar, a hero of the resistance who had led the French Forces of the Interior in eight departments of eastern France and had liberated the city of Nancy in Lorraine in late 1944, chose Emile Marchais, Vichy police superintendent of Lyon during the war, as his secretary general in French occupied Saarland. ${ }^{37}$

By mid-September 1945 the French civilian administration, with Baden-Baden as its capital, was in place: Maurice Sabatier became head of administrative affairs, Guy Périer de Féral was assistant director of administrative affairs, Jean Filippi directed the department of economy and finance, Jean Cabouat became head of security and Jean Lacombe became director of personnel in the zone. The heads of security and personnel both had assistant directors who also had a

und Kriegsopferversorgung im Rahmen französischer Besatzungspolitik (Mainz: v. Hase \& Koehler, 1988); Corine Defrance, La politique culturelle de la France sur la rive gauche du Rhin, 1945-1955 (Strasbourg: Presses Universitaires de Strasbourg, 1994); Alain Lattard, Gewerkschaften und Arbeitgeber in Rheinland-Pfalz unter französischer Besatzung 1945-1949, Veröffentlichungen der Kommission des Landtages für die Geschichte des Landes Rheinland-Pfalz 11 (Mainz: v. Hase u. Koehler, 1988) and Dietmar Hüser, Frankreichs 'doppelte Deutschlandpolitik': Dynamik aus der Defensive - Planen, Entscheiden, Umsetzen in Gesellschaftlichen und Wirtschaftlichen, Innen- und Aussenpolitischen Krisenzeiten: 1944-1950 (Berlin: Duncker \& Humblot, 1996).

33 For the notorious conflict between General Koenig and Emile Laffon, see, for instance, Alain Lattard, 'Zielkonflikte französischer Besatzungspolitik in Deutschland. Der Streit Laffon-Koenig 1945-1947', Vierteljahrshefte für Zeitgeschichte (1991), 1-35. The literature suggests that Koenig was more conservative in his views of Germany, while Laffon was portrayed almost as a socialist, who had progressive but realistic ideas and opted for a more radical change of Germany.

34 See footnote 22 .

35 Laffon had been responsible for the recruitment of the French prefects after the Liberation together with Michel Debré. See Archives Sciences Po Paris. Fonds Grimaud I, dossier 3, éléments biographiques, essai de C.V., no date, 19.

36 The younger administrators were, for instance, Maurice Grimaud or Pierre Bolotte, see section Experience, Merit and Inherited Hierarchies. Laffon, however, insisted in a letter to General Koenig that the decision to hire Cabouat as head of security was a choice under constraint: Laffon had foreseen another position for Cabouat, but he had no other options available and considered Cabouat would fill in this position only temporarily. See Archives Sciences Po Paris. Fonds Grimaud. GRI 4. Dossier 2 Occupation en Allemagne 1945-47. 1er Dossier: Les personnes. Correspondance Laffon. L'Administrateur Général Laffon Adjoint pour le Gouvernement Militaire de la Zone Française d'Occupation to Monsieur le Général de Corps d'Armée Commandant en Chef Français en Allemagne, Baden-Baden, 25 Jun. 1946, 1.

37 MAE 1PL 2956 Marchais, Emile. Intelligence note on Emile Marchais, no date. Marchais finally became secretary general in Württemberg working for Governor Guillaume Widmer. 
The Military Government of the French Zone of Occupation

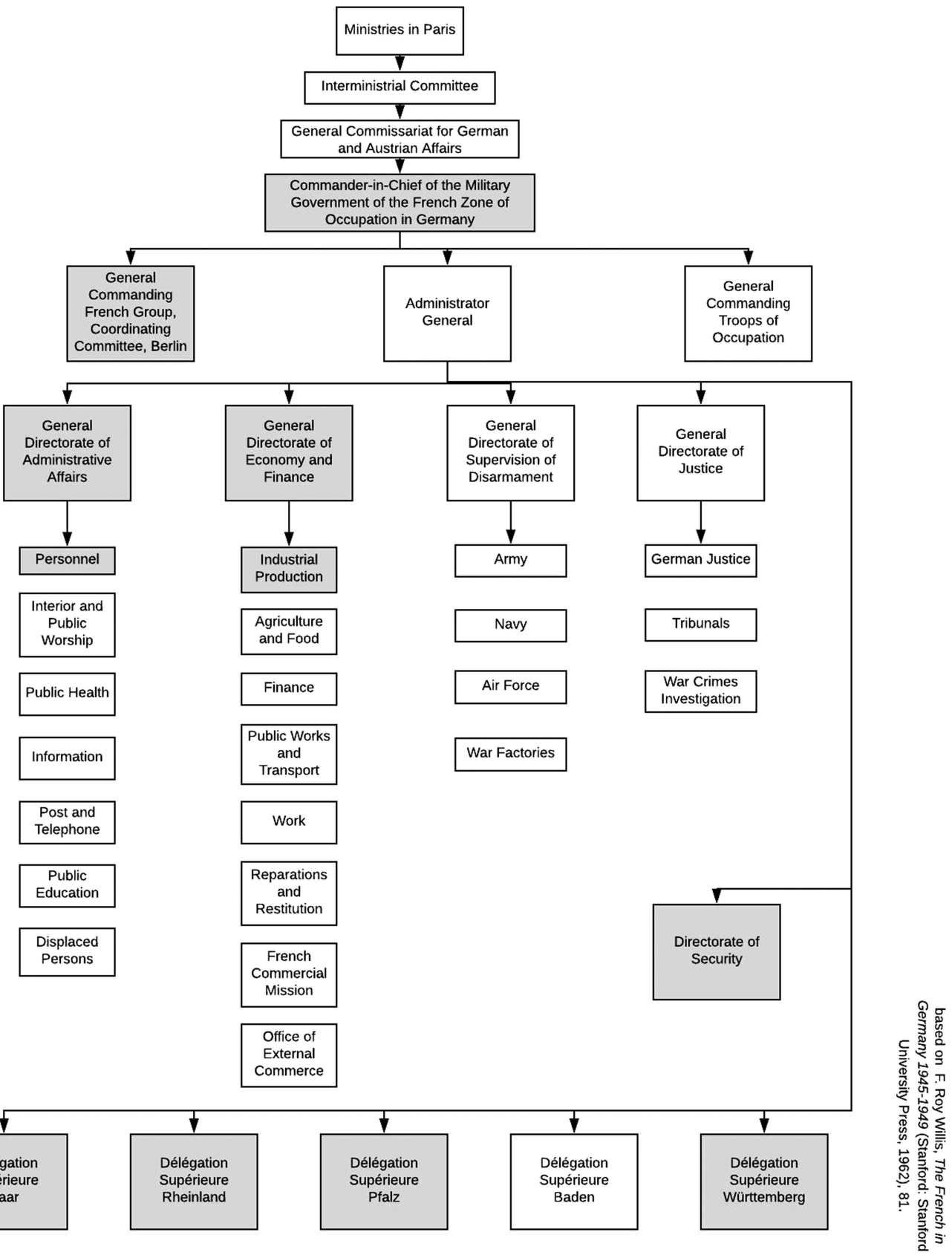

Figure 1. The organisation of the military government of the French zone of occupation (January 1946), presence of former Vichy administrators 
Vichy background. A number of former Vichy administrators became secretary-generals in the military government of the provinces Württemberg, Saar, Palatinate and Rhineland respectively. ${ }^{38}$ The diagram above outlines the departments of the French military government in which former Vichy officials found new employment. Moreover, the diagram reveals that the former Vichy officials took over the highest positions in the French military government, many at the centre of control in the capital of Baden-Baden.

\section{The Discovery of the Vichy Administrators and the Purge Commission}

Left-wing journalists were the first to scandalise the public by revealing the presence of Vichy officials in the French zone of occupation, but they were not the first to notice their presence in Baden-Baden. Instead, the colleagues of these Vichyssois in the French capital of Germany were the first to note their presence. They were young officials who came of age during the German occupation of France, untainted and true supporters of de Gaulle. Pierre Bolotte, aged twentythree, was one of them. He became Emile Laffon's chief of staff in Baden-Baden in September 1945. In a private letter dated 14 September 1945, written only three weeks after he had arrived in Baden-Baden, Bolotte expressed his surprise about his new colleagues:

I have . . . the curious feeling that Baden-Baden has become the last refuge, like Vichy . . Thus, I can ... greet - in the halls of the hotel where the offices of the general government are set up and that bear a striking similarity with the 'hôtel du Parc' [seat of the Vichy government] - in the prefectural corps, of which I will not say that I 'have the honour to belong to'!, Monsieur Sabatier, former regional prefect of Bordeaux plus a collection of ten to twelve dismissed prefects that are hardly one bit better . . . and, I do not speak of the sub-prefects, because then I would need a directory of $1943 .^{39}$

It did not take long for the rumours about Vichy officials haunting the hallways of expensive hotels in the old spa-town of Baden-Baden to reach the French capital. In late autumn 1945 newspapers mercilessly spread the news that officials at the ministries of interior and of foreign affairs had tried to keep quiet: these officials in Paris had so far ignored men like Bolotte, who had gone to Germany 'to serve France and the cause of peace', were shocked about the presence of Vichy officials there, but had 'knocked on the doors of the ministries and administrations without being heard', as Combat wrote. ${ }^{40}$

In December 1945 the complaints found their way into the French Constituent National Assembly, where the issue of Vichy officials in Germany was finally discussed. On 21 December 1945, Pierre Bourdan, ${ }^{41}$ from the non-communist left resistance party Democratic and Socialist Union of the Resistance (Union démocratique et socialiste de la Résistance; UDSR), brought forward a proposition in the name of the ministry of foreign affairs to send out a commission of inquiry to the French zones of occupation in Germany and Austria. The commission of inquiry, Bourdan emphasised, was not simply a response to public criticism regarding the French administration of Germans. The presence of Vichy officials was well-known to the ministry of foreign affairs, he asserted. But some of the criticism was 'sufficiently justified to nominate a commission of inquiry. ${ }^{42}$ The commission of inquiry therefore had the task of collecting information, of identifying weaknesses, and of remedying the manifold problems in the French zone - and most importantly of inquiring about 'the nature of the French personnel employed in France and Austria'. ${ }^{43}$ Bourdan further explained this point: 'we do not always feel - and this is a

\footnotetext{
38 AN C//15893 Commission d'enquête et d'information sur les zones d'occupation française d'Allemagne et d'Autriche, Rapport Général, 9 Apr. 1946, 11.

39 Archives Sciences Po Paris. Fonds Bolotte, Letter to H. Richard, 14 Sept. 1945.

40 'Civile Ou Militaire', Combat, 8 Nov. 1945.

41 French journalist at Radio Londres from 1940-4 and war correspondent accompanying the French army into Germany.

42 France, Journal Officiel de la République française, Débats de l'Assemblée Constituante, 16, 21 Dec. $1945,291$.
} 
euphemism - that the personnel is always in line with the democratic aspirations of the new France in terms of their [political] leaning. ${ }^{44}$ Bourdan and the ministry of foreign affairs feared the loss of French standing, both in regards to their fellow allies and in the eyes of the Germans, and thus wanted to emphasise that France in 1945 was a democratic country and able to occupy Germany.

The constituent national assembly subsequently voted to send a commission of inquiry composed of thirty-six members of all political parties to the French zones in Germany and Austria. The commission toured the territory for three weeks in February 1946. In Baden-Baden it became instantly known as 'purge commission' looking for former Vichy officials. ${ }^{45}$ The commission's head was Salomon Grumbach, an 'old militant socialist of Jewish and German origin' with an imposing personality. The former Vichy administrators in Baden-Baden were 'worried, very worried', because they knew Grumbach would not tolerate 'those people' in the French zone. ${ }^{46}$ However, as we will see, their concerns were unfounded.

It took the commission of inquiry almost seven weeks to record their impressions of the French occupation zone, to discuss their findings and to come up with a resolution. But the issue of the Vichy administrators was so pressing that Grumbach dispatched a letter to René Mayer, high-commissioner of German and Austrian affairs, only seven days after the commission had returned to France. The letter contained a note approved by all members of the commission of inquiry on the composition of the personnel of the civilian administration of Germany and underlined the impossibility of employing 'state officials of authority that had served in a relatively continuous way' in the Vichy government and then in Germany. ${ }^{47}$ According to this note, France's prestige in Germany and the success of the French occupation required that the leading positions in the French administration of Germany were instead given to, 'men whose vigilant patriotism was never called into question, and whose general attitude (acts and statements) bespeak no anti-democratic sentiment that could encourage the Nazis'. ${ }^{48}$ The commission of inquiry's note ended with a non-exhaustive list of thirteen former Vichy officials in the service of the French administration in Germany whose dismissal the commission strongly suggested. ${ }^{49}$

Based on these recommendations, the French national assembly unanimously adopted a resolution on the French occupation of Germany on 24 April 1946. It included an instruction about the presence of former Vichy officials in the French zone:

${ }^{43}$ France, Journal Officiel de la République française, Débats de l'Assemblée Constituante, 16, 21 Dec. 1945, 291.

44 France, Journal Officiel de la République française, Débats de l’Assemblée Constituante, 16, 21 Dec. 1945, 291.

45 Archives Sciences Po Paris. Fonds Bolotte, Dossier 1, Allemagne 1945-1946, Divers documents. Note for Laffon or Bolotte, Baden-Baden, 18 Mar. 1946.

46 SHD Archives orales, $3 \mathrm{~K}$ 49, Bolotte. Entretien 2, plage. Born in German Alsace in 1884, Grumbach was a member of the German Social Democratic Party (Sozialdemokratische Partei Deutschlands; SPD) before the First World War and became French citizen only in 1918 when he entered the French equivalent of the SPD (La Section Française de l'Internationale; SFIO). Grumbach joined the French maquis during the German wartime occupation and became head of the commission of foreign affairs within the constituent assembly, a commission he had already been a member of in the interwar period.

47 AN C//15893 Assemblée Nationale, Zone d'Occupation Française d'Allemagne et d'Autriche, Rapports. Note 4, Salomon Grumbach, 3 Apr. 1946.

48 AN C//15893 Assemblée Nationale, Zone d'Occupation Française d'Allemagne et d'Autriche, Rapports, 10. Note 1 concernant la composition du personnel de l'Administration civile ('Gouvernement militaire').

49 AN C//15893 Assemblée Nationale, Zone d’Occupation Française d’Allemagne et d'Autriche, Rapports, 10. Note 1 concernant la composition du personnel de l'Administration civile ("Gouvernement militaire"), Liste de fonctionnaires dont le maintien à leurs postes paraît inopportun à la Commission parlementaire d'enquête. Among those thirteen administrators were the above-mentioned Maurice Sabatier (General Director of Administrative Affairs), Jean Filippi (General Director of Economy and Finance), Guy Périer de Féral (Deputy General of Administrative Affairs), Jean Cabouat (Director of Security), Jean Lacombe (Director of Personnel), Emile Marchais (Secretary General of Württemberg) and Francis Thiallet (Secretary General of the Palatinate). The remaining five undesirables were Raymond Viguié (Deputy Director of Security), Philippe Coste (Director of Industrial Production), Edouard Kuntz (Assistant to the Governor of the Saar), Marcel Chapron (Deputy Director of Personnel), Pierre Ordonneau (Deputy Director to General Koenig) and Pierre Landron (Secretary General of the Rhineland). 
To proceed without delay to the elimination of people, on all levels of the civilian administration and of the army, that were compromised under the regime called 'French State' ... and to sanction all members of the French civilian administration or the army guilty of keeping up friendly relationships with Nazis. ${ }^{50}$

Emile Laffon, the head of the military government, did indeed try to meet the commission's demands and sent former Vichy officials home. Shortly after the purge commission left, a veritable bargaining began, notably over the fate of Périer de Féral, secretary general of Paris under Vichy, and Sabatier, the former regional prefect of Bordeaux. Pierre Bolotte, Laffon's young chief of staff in Baden-Baden, recalled a meeting at Laffon's private residence, the Jesuitenschlösschen, the night after a dinner honouring the commission of inquiry, where the fate of Périer de Féral and Sabatier was decided. Grumbach had advised Laffon to fire both, stating: '[their presence in Germany] is not possible'. ${ }^{51}$ But Laffon decided, in the words of Bolotte: 'ah, not the two of them, we give one of them the chop'. ${ }^{52}$ So Laffon, Bolotte and Maurice Grimaud, director of Laffon's cabinet in Baden, decided whom of the two to dismiss. At the end of the night the blow fell on Périer de Féral. The decision was influenced by the power Sabatier still held in Baden-Baden compared to Périer de Féral: Bolotte explained that 'keeping the other [Périer de Féral], would have meant diminishing [Sabatier], in a certain way'. ${ }^{53}$ And it seems that this was simply not possible. Périer de Féral therefore quit his position in the French occupation zone on 30 June 1946, in what was officially declared a 'budgetary measure'. ${ }^{54}$

The dismissal of Périer de Féral was, however, only for the sake of appearances. In the summer of 1946 the communist newspaper L'Humanité pointed out that the constituent assembly's claim to have removed thirteen former Vichy officials had, by no means, been met: most of them were still in Germany. ${ }^{55}$ They were still there because Emile Laffon, the former resister, explicitly refused a second wave of purges in the spring of 1946, adopting his rule: 'no second purge' (literally: 'no purge on another purge'). ${ }^{56}$ Laffon explained that all Vichy officials in Germany had gone through the French purge commission of 1944-5 and were either fully reinstated, or reinstated but sanctioned with a minor punishment. ${ }^{57}$ Thus, regardless of the commission of inquiry's list of undesirables, of the decision taken in the constituent assembly and of French public opinion, the former Vichy administrators remained in Germany.

Indeed, the only reason Laffon sent any Vichy administrators back to France was due to their offensive or deficient behaviour in Germany. One Vichyssois was removed because he had raped a woman from the Saar in late $1945 .^{58}$ Cabouat, the fallen prefect of Pas-de-Calais, had to leave because he had employed a supposed young hero of the resistance as his assistant at the head of the security for the French zone, who had later turned out to be a trickster who had fabricated his entire career in the resistance altogether. ${ }^{59}$ And finally, a third Vichyssois was sent back to France because his services were no longer needed in the position he held. ${ }^{60}$

\footnotetext{
50 France, Journal Officiel de la République française, Débats de l'Assemblée Constituante, 55, 24 Apr. 1946, $2208-9$.

51 SHD Archives orales, 3 K 49, Bolotte. Entretien 2, plage 12.

52 SHD Archives orales, 3 K 49, Bolotte. Entretien 2, plage 12.

SHD Archives orales, $3 \mathrm{~K} \mathrm{49}$, Bolotte. Entretien 2, plage 12.

4 AN F1bI 1105 Périer de Féral, Guy. Pièces diverses.

55 A. Biscarlait, 'En zone d'occupation française ce sont toujours les Vichyssois qui commandent', L'Humanité, 26 Sept. 1946.

56 AN C//15893 Assemblée Nationale, Zone d'Occupation Française d'Allemagne et d'Autriche, Rapports. Audiences, M. Laffon, Administrateur Général de la Zone, 9 Jul. 1947, 5.

57 AN C//15893 Assemblée Nationale, Zone d'Occupation Française d'Allemagne et d'Autriche, Rapports. Audiences, M. Laffon, Administrateur Général de la Zone, 9 Jul. 1947, 5.

58 This was the case of Edouard Kuntz, see MAE 1PL 2434 Kuntz, Edouard.

59 See AN F1bI 1127 Cabouat, Jean.

60 See MAE 1PL 2956 Marchais, Emile.
} 


\section{Experience, Merit and Inherited Hierarchies}

It is thus striking that an administrator's past in Vichy did not hinder him from remaining employed in Germany. What was more important to the new French government was the expertise these administrators had gained during their career and the way they applied their knowledge to successfully occupy Germany. In other words, their merit in the French zone was crucial for them remaining in Germany beyond the spring of 1946.

The case of the head of the directorate of finance and economic affairs in occupied Germany, Jean Filippi, illustrates this policy. During the war Filippi had led the minister of finance's cabinet, was secretary general of economic affairs and was head of the French railway company SNCF. ${ }^{61}$ In Germany he was very successful at organising the reconstruction of the economy in the immediate post-war period. He was also responsible for the extraction of German goods used to repair the damage caused by both the war and German occupation in France. Emile Laffon's recommendation in support of Filippi's nomination for chevalier of the Legion of Honour in 1947 underlines Filippi's extraordinary contribution to the success of the French occupation of Germany:

From [Filippi] stems an essential part of the merit of what we can call today a success, that means an occupation that - without having been costly for the French treasury - placed important wealth at the metropolitan economy's disposal. At the same time, the occupation maintained an essential economic balance within the zone without which no durable politics could have been possible. ${ }^{62}$

His usefulness to France, and to the new Fourth Republic, was what counted in the aftermath of the Second World War, not his past. As head of the economy and finance department, the equivalent of a minister of finance in France, he was responsible for realising the contradictory and ill-defined economic policy for the French zone: extracting reparations for the French economy while democratising and keeping the German industries alive - all without investing French funds into German recovery or feeding the zone, which would have been impossible to justify to the French public as well as government. With a ravaged country at home, helping the Germans recover was certainly not in the French general interest; on the contrary, they expected notably security and reparations. ${ }^{63}$ Filippi did not fail to put forward his views and warned about the lack of a clearly defined economic strategy and that the mere satisfaction of short-term interests in Germany was insufficient. ${ }^{64}$ Despite his position and expertise, he failed to impose his expert opinion on the government in Paris or in Germany, mainly because France had political and not economic priorities in the zone. For instance, Filippi suggested centralising the German economy of the zone, but given the preoccupation with decentralising German institutions as much as possible, his suggestions were dropped by General Koenig's camarilla. ${ }^{65}$ Martial Libera suggests that Filippi was more moderate in his criticism than some of his co-workers in BadenBaden. ${ }^{66}$ Filippi's reserve could possibly be due to his status as tainted Vichy administrator, but he was indeed dependent upon the instructions from the government - just as he had been

${ }^{61}$ On Filippi's career path see MAE 1 PL 1610 Jean Filippi and Martial Libera, Un rêve de puissance : la France et le contrôle de l'économie allemande (1942-1949) (Bruxelles: Peter Lang, 2012), 313.

${ }^{62}$ MAE 1PL 1610 Filippi, Jean. Dossier de préparation à la Légion d’Honneur. Laffon on Filippi, no date.

63 Those goals were similar to the French policies towards Germany in the aftermath of the First World War, see: Anna Lauter, Sicherheit und Reparationen. Die französische Öffentlichkeit, der Rhein und die Ruhr 1918-1923 (Essen: Klartext Verlag, 2006). Some French politicians dreamed of a quasi-imperial takeover of the German economy to forge into the lead as continental European economic power in the aftermath of the Second World War, which Libera has called 'a dream of power'. See the title of Martial Libera, Un rêve de puissance : la France et le contrôle de l'économie allemande (1942-1949) (Bruxelles: Peter Lang, 2012).

${ }^{64}$ See Martial Libera, Un rêve de puissance : la France et le contrôle de l'économie allemande (1942-1949) (Bruxelles: Peter Lang, 2012), 230, 592.

65 This is yet another example of how the conflict between Koenig and the Laffon influenced French policies in the zone. 
dependent upon the Vichy government and the German occupiers during the war. In Germany he had to navigate the power dynamics between General Koenig, Laffon and the various Parisian ministries involved in governing the zone. According to the French government, Filippi managed all this quite well as he was eventually awarded the chevalier of the legion of honour. The decoration publicly demonstrated his ability to use not only his expertise but also the German economy to serve the new France: his departure from the position in 1948 marked the shift from a tight French control of the zone to a gradual handing over of economic affairs to the Germans. ${ }^{67}$ Filippi is therefore a good example of the political flexibility of technocrats in the 1940s who were ready to put their expertise into the service of their government, whichever government they served.

It was relatively easy for the Vichyssois to prove their merit and worth to the new French Republic since they held similar positions to those they had already held in occupied France and, indeed, throughout their long careers in the French administration. Filippi is a case in point: one of his young colleagues in Baden-Baden later confirmed in an interview the similarity of Filippi's tasks and the need for Filippi's expertise in occupied Germany based upon his experience in the Vichy administration:

[Filippi] was a very honest man, but he was above all a very competent man, very skilful, who knew his business very well and he remarkably organised his general division of financial and economic affairs, with . . . the farsightedness of a man who had participated in a government even if that government was [laughing] the wrong government, nonetheless [laughing] the problems remain the same. ... So, he had worked on the level of a minister, helped him with his work, he knew how to get a very big machine to work. ${ }^{68}$

The former Vichy administrators furthermore mutually supported each other. The head of administrative affairs and the head of personnel in the French zone were both former Vichy administrators, and they were responsible for signing the yearly evaluations of their colleagues. Some had already worked together in the prefectural administration of Vichy, and, unsurprisingly, they all received very positive feedback on their work in Germany. The evaluation of Vichyssois by Vichyssois, especially in the first months of the French occupation in Germany, was frequent, and old institutional sympathies among prefectural senior executives remained strong well after the liberation. Those sympathies also provided the basis for the future success of those well-rated administrators - which meant that they could stay in Germany despite both the commission of inquiry's decisions and those of the parliament.

Finally, their acquired rank in the administrative hierarchy - regardless of the political composition of the government that employed them - was important for their continued service in Germany. The thirteen undesirables found by the commission had all worked their way up the state system already in the Third Republic and had a considerable amount of experience in administration that many of the younger occupiers from the resistance lacked. More importantly, their titles remained valid after the war and during the French occupation of Germany. A prefect remained a prefect by name and was called 'Monsieur le préfet' even if his position was head of security or administrative affairs in the French military government of Germany. Their title or function - even during the Vichy regime - earned them respect among their colleagues and

\footnotetext{
66 See Martial Libera, Un rêve de puissance : la France et le contrôle de l'économie allemande (1942-1949) (Bruxelles: Peter Lang, 2012), 195. In a review of Martial Libera's book the economic historian Marcel Boldorf noticed that Libera did not address the Vichy administrators' role and influence on the French policies in Germany. See Marcel Boldorf, review of Un rêve de puissance : la France et le contrôle de l'économie allemande (1942-1949), by Martial Libera, Francia-Recensio, 2013-4, 19./20. Jahrhundert - Histoire contemporaine, https://www.recensio.net/rezensionen/zeitschriften/franciarecensio/2013-4/19-20-jahrhundert-histoire-contemporaine/un-reve-de-puissance (last visited 10 July 2018).

67 Martial Libera, Un rêve de puissance : la France et le contrôle de l'économie allemande (1942-1949) (Bruxelles: Peter Lang, 2012), 595.

68 MAE AOR 14 Grimaud, Maurice.
} 
subordinates. Pierre Bolotte, Laffon's chief of staff, perfectly explained this relationship between those old administrators and the young in Baden-Baden:

I wasn't anything important in the prefectural corps, because I was twenty-three years old. ... But we still had a hierarchical grouping, which means that, well, I was head of a prefect's cabinet, and Sabatier or Péral were prefects of a much higher level, they were no longer prefect but they remained prefect. They had ... a very long and complete experience and usually the expression of respect towards those prefects was inevitable . . it facilitated their existence. ${ }^{69}$

\section{The Vichy Administrators, Germans and Allies}

The average German in the French zone was probably not aware of the presence of the former Vichy administrators. Their presence went largely unnoticed because the central administration in Baden-Baden, where the majority of the thirteen Vichy administrators worked, was rather detached from the German population. ${ }^{70}$ The rudimentary German administration that existed on the local level was entirely subordinated to the French military government and was furthermore preoccupied with more urgent matters of food supply and reconstruction in the immediate aftermath of the war. There was suspicion of the French occupiers among the German population because of the long history of French-German dualism, and many Germans considered themselves victims of French revenge after four years of Nazi occupation in France. ${ }^{71}$ But even if the Germans had noticed the presence of Vichy administrators, they had few means through which to protest since, up to 1948, all publications and the press in the French zone were censored. ${ }^{72}$ Moreover, the French occupiers also censored their own newspapers in the zone if they were too critical of French rule in Germany. ${ }^{73}$ For those Germans who were tainted as National Socialists themselves, the presence of the former Vichy administrators in the French zone might have had more advantages than inconveniencies. They and the Vichyssois shared a common history of involvement with Nazism that both hoped to be forgotten as quickly as possible. Therefore, they showed little interest in denouncing the Vichy administrators, and even less interest as they were constantly under threat to be 'purged' themselves. ${ }^{74}$

The French denazification policy was modelled on the purges in France. While French policy in occupied Germany was, in principle, designed to control the German administration and

69 MAE AOR 13 Bolotte, Pierre.

70 MAE AOR 1 Humbert, Roger.

${ }^{71}$ See Rainer Möhler, 'Politische Säuberung im Südwesten unter französischer Besatzung, in Kurt Düwell and Michael Matheus, eds., Kriegsende und Neubeginn: Westdeutschland und Luxemburg zwischen 1944 und 1947 (Stuttgart: Steiner, 1997), 175-92; Edgar Wolfrum, 'Das Bild der "düsteren Franzosenzeit". Alltagsnot, Meinungsklima und Demokratisierungspolitik in der französischen Besatzungszone nach 1945', in Stefan Martens, ed., Vom 'Erbfeind' zum 'Erneuerer'. Aspekte und Motive der französischen Deutschlandpolitik nach dem Zweiten Weltkrieg (Sigmaringen: Thorbecke, 1993), 87-113 and Rainer Hudemann, 'L'occupant français et la population allemande après deux guerres mondiales', Relations Internationales 80 (1994), 471-89. Of those three publications only Möhler mentions the presence of Vichyssois as one reason for the German scepticism towards the French occupiers but does not provide any evidence for this claim.

72 See MAE AP 150, Sanctions contre la presse 1946-1948 and MAE AP 150/4 Régime de censure (1945-1948).

73 'Interdit en Allemagne à cause des révélations de notre envoyé spécial Jacques Morel. France d'Abord continuera de démasquer ceux qui complotent contre la République', France d'Abord, 12 Jun. 1947.

${ }^{74}$ My sources do not mention the way former Nazis perceived the French Vichyssois; more research needs to be done on that issue. The parallels between the French sidelining of Vichyssois and the temporary going underground of former Nazi officials, however, are striking, see for instance Dominik Rigoll, 'From Denazification to Renazification? West German Government Officials after 1945', in Camilo Erlichman and Christopher Knowels, eds., Transforming Occupation: Power Politics, Everyday Life, and Social Interactions in the Western Zones of Occupied Germany, 1945-1955 (London: Bloomsbury 2018, 252-69. In fact, many European nations struggled coming to terms with their experiences in the Second World War. See, for example, Kerstin von Lingen, ed., Kriegserfahrung und nationale Identität in Europa nach 1945. Erinnerung, Säuberungsprozesse und nationales Gedächtnis (Paderborn: Schöningh, 2009). 
economy and avoided giving the Germans any power over their fate, it is surprising that, in practice, this was not the case in matters of denazification. French denazification policy relied on the purge of Germans by Germans, similar to and inspired by the purges in France where resisters passed judgment on collaborators. ${ }^{75}$ This concept of 'self-purges' (auto-épuration) as applied by Emile Laffon, assessed individual guilt case by case depending on the level of personal implication with the Nazi regime. Laffon had originally planned to purge only convinced Nazis in the upper levels of the administration and to identify those who were willing to work with the French to build a democratic regime - again similar to his attitude vis-à-vis the former Vichy administrators. ${ }^{76}$ The French administration had also tried to win over Nazi-tainted Germans to form a pro-French separatist movement in the land of Baden by offering them a lenient denazification process if they collaborated. ${ }^{77}$ This was also similar to the Vichy administrators who were 'on probation' in Germany where they worked with and for the new democratic French Republic.

Unlike the American occupiers who punished the Germans automatically on account of their membership in the Nazi party, the French approach was that the local community could best evaluate a suspected Nazi's behaviour during the twelve years of National Socialism. ${ }^{78}$ Indeed, the Germans themselves praised the French system highly. One report from Baden and Württemberg about the German perception of the French denazification stated in February 1946:

The Germans pay homage to the French methods of purges and to the common sense the administrators demonstrate in this matter. The French, so they say, distinguish themselves from the Americans in that they are capable of a certain perceptiveness, enter in the conscience of the people they have to judge (they are capable of Einfühlung [empathy]), and endeavour to treat every case individually in that they take into account the circumstances. Their method does not have the schematic and oftentimes odious nature that the allied powers unfortunately use. Their denazification is rigorous and it has to be like that. But it is at the same time just and nuanced. ${ }^{79}$

However, while the French system was admired and even copied by the Americans, in practice, it turned out to be inefficient in purging the Nazis in Germany for similar reasons the

75 The historiography on denazification in the French zone underlines the influence of the purges the French themselves had experienced in France at the end of the war on the French purges of the Nazis but without going into further detail and without making the connection between the negligence practiced in France and the way the French carried out the purges in Germany. See, for example, Klaus-Dietmar Henke, Politische Säuberung unter französischer Besatzung: die Entnazifizierung in Württemberg-Hohenzollern (Stuttgart: Deutsche Verlags-Anstalt, 1981), 25. See also Rainer Möhler, 'Politische Säuberung im Südwesten unter Französischer Besatzung', in Kurt Düwell and Michael Matheus, eds., Kriegsende und Neubeginn. Westdeutschland und Luxemburg zwischen 1944 und 1947 (Stuttgart: Franz Steiner Verlag, 1997), 175-92; as well as Reinhard Grohnert, Die Entnazifizierung in Baden, 1945-1949: Konzeptionen und Praxis der 'Epuration'am Beispiel eines Landes der französischen Besatzungszone (Stuttgart: Kohlhammer, 1991), 59. See also Dietmut Majer, Review of Entnazifizierung in Rheinland-Pfalz und im Saarland unter französischer Besatzung von 1945 bis 1952 by Rainer Möhler, Politische Vierteljahresschrift 37, 1 (March 1996), 161-2.

76 Reinhard Grohnert, 'Die "auto-épuration”- Der französische Sonderweg in der Entnazifizierung', in Edgar Wolfrum, Peter Fässler and Reinhard Grohnert, eds., Krisenjahre und Aufbruchszeit: Alltag und Politik im französisch besetzten Baden, 1945-1949 (Munich: Oldenbourg Verlag, 1996), 167.

77 Klaus-Dietmar Henke, Politische Säuberung unter französischer Besatzung: die Entnazifizierung in WürttembergHohenzollern (Stuttgart: Deutsche Verlags-Anstalt, 1981), 43.

78 On the self purges see Reinhard Grohnert, 'Die “auto-épuration”- Der französische Sonderweg in der Entnazifizierung', in Edgar Wolfrum, Peter Fässler and Reinhard Grohnert, eds., Krisenjahre und Aufbruchszeit: Alltag und Politik im französisch besetzten Baden, 1945-1949 (Munich: Oldenbourg Verlag, 1996), 165-85, as well as the chapters on autoépuration in Reinhard Grohnert, Die Entnazifizierung in Baden, 1945-1949: Konzeptionen und Praxis der 'Epuration'am Beispiel eines Landes der französischen Besatzungszone (Stuttgart: Kohlhammer, 1991), 67-181.

79 Archives Sciences Po Paris. Bolotte, Pierre. Dossier 1, Allemagne 1945-1946. Divers documents. Observations faites au cours d'un voyage en Bade et Württemberg par le Capitaine R. de Naurois entre le $1^{\mathrm{e}}$ février et le 12 février 1946, no date. 
French purges themselves were unsuccessful. ${ }^{80}$ The failure of denazification had nothing to do with the decisions the German purge committees took but rather with the deficient implementation of their decisions: some of the French military governments in the provinces joined forces with the German heads of the administrations and simply ignored the decisions of the purge commissions. ${ }^{81} \mathrm{~A}$ well-known example of this practice was in the case of forestry, where French interest in the economic resources of Germany was more important than a complete denazification and tainted but experienced German forestry officials remained in place. ${ }^{82}$ In the first year of the occupation Emile Laffon himself had ordered that the dismissal of specialists in the German administrations be slowed down. ${ }^{83}$ And his chief of staff, Pierre Bolotte, underlined in 1999 in an oral history interview that denazification had not been priority at all in the French zone during the first six months of the occupation. ${ }^{84}$ The French government in Paris was not interested in the denazification of the French zone as a whole even for the first two years of the occupation because of their interest in extracting reparations for France and thus requiring first and foremost a functioning administration and economy. ${ }^{85}$ It is therefore no surprise that the commission of inquiry sent to Germany in the spring of 1946 noticed that, '[i]n too many localities ... authentic Nazis have been put back into office because of their supposedly technical qualities' ${ }^{86}$ This fact constitutes a clear parallel to the continued presence of Vichy officials in the French zone: the latter were also chosen to serve in Germany because of their technical skills in matters of administration. Similar to the purges in France, where passing through a purge commission became more of a mere symbolic procedure, the purges in French occupied Germany lost their importance quickly. ${ }^{87}$ The neglect of Laffon's initial directive to focus on purging convinced Nazi ideologues at the top of the administration, the sheer numbers of denazification files and the pressure to complete the purges turned denazification from a political process into a mere bureaucratic exercise. ${ }^{88}$ The French administration and the German public tried to end the

${ }^{80}$ The Americans took over the French two-chamber system. See Klaus-Dietmar Henke, Politische Säuberung unter französischer Besatzung: die Entnazifizierung in Württemberg-Hohenzollern (Stuttgart: Deutsche Verlags-Anstalt, 1981), 8 and Reinhard Grohnert, Die Entnazifizierung in Baden, 1945-1949: Konzeptionen und Praxis der 'Epuration' am Beispiel eines Landes der französischen Besatzungszone (Stuttgart: Kohlhammer, 1991), 63.

81 Reinhard Grohnert, 'Die “auto-épuration”- Der französische Sonderweg in der Entnazifizierung', in Edgar Wolfrum, Peter Fässler and Reinhard Grohnert, eds., Krisenjahre und Aufbruchszeit: Alltag und Politik im französisch besetzten Baden, 1945-1949 (Munich: Oldenbourg Verlag, 1996), 172.

82 See, in the case of forestry, Reinhard Grohnert, Die Entnazifizierung in Baden, 1945-1949: Konzeptionen und Praxis der 'Epuration'am Beispiel eines Landes der französischen Besatzungszone (Stuttgart: Kohlhammer, 1991), 95-9.

83 Reinhard Grohnert, 'Die “auto-épuration”-Der französische Sonderweg in der Entnazifizierung', in Edgar Wolfrum, Peter Fässler and Reinhard Grohnert, eds., Krisenjahre und Aufbruchszeit: Alltag und Politik im französisch besetzten Baden, 1945-1949 (Munich: Oldenbourg Verlag, 1996), 173.

${ }^{84}$ When asked about his involvement in denazification, Bolotte replied: 'Not at all, not at all. Never. No. Moreover, this [the denazification] was not on the agenda in the first six months [of the occupation], you understand? It was not on the agenda.' SHD Archives orales, 3 K 49, Bolotte. Entretien 2, plage 17.

85 See Angela Borgstedt, 'Dénazification - épuration dans l'Allemagne d'après-guerre', Revue d'Allemagne et des Pays de langue allemande, 40, 2 (2008), 243. Paris did not even send the minimal number of judicial employees required for the denazification to Germany; see Reinhard Grohnert, Die Entnazifizierung in Baden, 1945-1949: Konzeptionen und Praxis der 'Epuration' am Beispiel eines Landes der französischen Besatzungszone (Stuttgart: Kohlhammer, 1991), 164.

86 AN C//15893 Assemblée Nationale, Zone d'Occupation Française d'Allemagne et d'Autriche, Rapports. Rapport présenté par M. Henri Wallon au nom de la Ière Section de la Commission parlementaire d'enquête chargée des questions administratives, 5 .

${ }^{87}$ See, for the symbolic meaning of the purges in France, François Rouquet, L'épuration dans l'administration française : agents de l'Etat et collaboration ordinaire (Paris: CNRS éditions, 1993), 233.

88 The shift to a mere nominal denazification took place at the latest at the turn of the year 1946-7, when the French zone took over of the rather static American denazification procedures, the Spruchkammerverfahren, see Reinhard Grohnert, 'Die "auto-épuration"- Der französische Sonderweg in der Entnazifizierung', in Edgar Wolfrum, Peter Fässler and Reinhard Grohnert, eds., Krisenjahre und Aufbruchszeit: Alltag und Politik im französisch besetzten Baden, 1945-1949 (Munich: Oldenbourg Verlag, 1996), 182. 
purges as soon as possible to return to 'normal' and to rebuild the country. ${ }^{89}$ The purges in the two countries therefore were both incomplete and full of loopholes.

My sources are silent about whether or not former Vichy administrators favoured the former Nazis or mingled with them, as newspaper articles in 1945 feared. However, former Vichy administrators were implicated in the denazification process. In 1947 Edgar Morin claimed in his book on the French zone that former Vichy magistrates took over positions in the directorate of justice. ${ }^{90}$ Maurice Sabatier - who himself had to go through a purge commission in 1944 in France - presided over German amnesty commissions in the late 1940s. Francis Thiallet, who had been police intendant (intendant de police) of Rennes (Brittany) in occupied France during the war, sent out instructions on the denazification of German administrations to the French commissioners as well as to the heads of German administrations in the district of Hessen-Palatinate, where Thiallet took care of the internal administrative affairs in $1946 .{ }^{91}$ Edouard Kuntz, who had been Vichy prefect of the Tarn department during the war and assistant to the delegate general Gilbert Grandval in the Saar after the war, was accused of protecting or at least tolerating Nazis in an article of the newspaper Ce Soir in November $1945 .^{92}$ Those accusations were also taken up in a 'Field report on the French zone in Germany' by the Washington D.C.-based organisation Foundation of Foreign Affairs, who found that the presence of former Vichy administrators obstructed denazification in the French zone, suggesting persisting bonds of solidarity between former Nazi and former Vichy administrators:

the action of the rightist elements, some of them formerly pro-Vichy, who are now important in the administration of the French zone, has frequently hindered a more complete 'denazification', and, indeed, has resulted in the installation of rightist elements in the main command posts of the German administration. ${ }^{93}$

This close association of former Vichy administrators and former Nazis in occupied Germany led to the 'detestable reputation' of the French zone among the Allies, Edgar Morin noted. He reported that the Allies, especially the Americans, considered it a 'hideout for Nazis that had been purged in the other zones'. ${ }^{94}$ Two newspaper articles had informed the American public about this issue. The New York Times noted in October 1945 that the French had employed twentyseven tax officials and elementary school teachers that had previously worked in the American zone, mostly in Karlsruhe. ${ }^{95}$ A French investigation found that the accusations were only partly

${ }^{89}$ Angela Borgstedt noted that in comparison to the American zone, the purges in the French zone were accomplished much faster. Angela Borgstedt, 'Dénazification - épuration dans l'Allemagne d'après-guerre', Revue d'Allemagne et des Pays de langue allemande, 40, 2 (2008), 247.

90 Edgar Morin, Allemagne notre souci (Paris: Hier et aujourd'hui, 1947), 65.

91 See SHD 3 U 251. Commandement en Chef des Forces Françaises en Allemagne, Cmt de la Zone d'Occupation Nord. Notes de la Délégation supérieur de Hesse-Palatinat. Note cd. la Dénazification des administrations 1945. Gouvernement Militaire de la Zone Française d'Occupation, Délégation Supérieur pour le Hesse-Palatinat, Affaires Administratives Intérieur. Confidentiel. Le Général Bouley, Délégué Supérieur pour le Gouvernement de Hesse-Palatinat to Messieurs les Délégués du Gouvernment Militaire. Dénazification des administrations, Neustadt, 14 Oct. 1945. See also Gouvernement Militaire de la Zone Française d'Occupation, Délégation Supérieur pour le Hesse-Palatinat, Affaires Administratives Intérieur. Confidentiel. Le Général Bouley, Délégué Supérieur pour le Gouvernement de Hesse-Palatinat to Monsieur l'Oberregierungspräsident à Neustadt. Dénazification des administrations, Neustadt, 10 Oct. 1945.

92 Jacques-Francis Rolland, 'La faillite de Baden-Baden. Sous l'égide de M. Kuntz les Nazis sarrois sont en place', Ce Soir, 20 Nov. 1945. Kuntz was one of the few Vichyssois who had to leave the zone, see footnote 58.

93 Foundation for Foreign Affairs, Washington D.C., Field Report on the French Zone in Germany, $1946,19$.

94 Edgar Morin, L'an zéro de l'Allemagne (Paris: Cité Universelle, 1946), 212.

95 See 'French use Nazis from U.S. District: American officer declares that men ousted by us have regained positions 27 office holders cited French shrug off protests', New York Times, 21 Oct. 1945. See also Reinhard Grohnert, Die Entnazifizierung in Baden, 1945-1949: Konzeptionen und Praxis der 'Epuration' am Beispiel eines Landes der französischen Besatzungszone (Stuttgart: Kohlhammer, 1991), 74. 
true and immediately dismissed the concerned German officials. Another accusation by the New York Herald Tribune was found untenable, Emile Laffon reported to General Koenig. ${ }^{96}$ While this accusation did not prove justified in the eyes of the French administration, it shows that they were concerned with the issue and feared rumours about a failed denazification in their zone. And, indeed, the French zone was struggling with denazification scandals - similar to their own 'little Vichy' scandal in Baden-Baden. Edgar Morin wrote of the French purges in Germany: 'every city is the theatre of a series of big and small purge scandals that outrage and then discourage the anti-Nazis, stun the rest of the population, and amuse the Nazis'. ${ }^{97}$ In the context of these purge scandals, Morin in particular looked to the example of the city of Baden-Baden both the capital of the French zone and the residence and workplace of the majority of former Vichy administrations.

Recent research literature on French denazification (which is still mostly from the early 1990s) has disputed the widespread opinion that the French zone was an 'Eldorado of tolerance'. ${ }^{98}$ The presence of the Vichy administrators in the French administration, that is in their own ranks, however, influenced the German purges - be it in an active way via their implication in the denazification procedures or in a passive way through the normalising effect the on-going presence of Vichy administrators had on the employment of Nazi-tainted Germans. The intimate knowledge of their shared Nazi and Vichy past distinguishes the relationship between French and Germans from the relationship between Germans and the other Allies, as the French approach and handling of the auto-épuration testifies. General Koenig claimed, in November 1945, that: 'the French administration in Germany is certainly the one which understands the Germans best because the French are those of the four occupying powers who have been most in contact with the Germans'. ${ }^{99}$ High level French bureaucrats (both from the resistance and from the Vichy administration) thus applied the same criteria towards the denazification of Germans in the French zone as they did towards their own countrymen and women in France, while their own experience with the purges in France rendered them more sensitive with regards to the complexities of wartime conditions.

Aside from a more or less pronounced critique of denazification in the French zone, the other Allies did not seem to have further intervened in either the French recruitment of personnel or the denazification of Germans. Maybe this was due to their own problems with purging Nazis in

96 Reinhard Grohnert suspected that the American press campaign against the French denazification measures merely distracted from their own denazification scandals and noted that the Americans employed at least three officials that had been formerly purged in the French zone. See Reinhard Grohnert, Die Entnazifizierung in Baden, 1945-1949: Konzeptionen und Praxis der 'Epuration'am Beispiel eines Landes der französischen Besatzungszone (Stuttgart: Kohlhammer, 1991), 75.

97 Edgar Morin, L’an zéro de l'Allemagne (Paris: Cité Universelle, 1946), 213.

98 Klaus-Dietmar Henke's study is representative of the 'Eldorado der Duldsamkeit'-interpretation of the French denazification policy. The newer studies tried to put forward the various circumstances that led to the failure of the French denazification instead of condemning too easily the French policy as such. Those fatal circumstances were the Parisian interest in a functioning administration and economy to extract reparations, the lack of organization and guidelines, the German criticism of punishing the small fishes instead the big ones, and the time pressure the purge commissions were in. See Volker Dotterweich, review of Die Entnazifizierung in Baden 1945-1949. Konzeptionen und Praxis der 'Epuration' am Beispiel eines Landes der französischen Besatzungszone by Reinhard Grohnert, Historische Zeitschrift, 260,1 (Feb.1995), 283-4. The newer studies include Möhler and Grohnert, see footnote 75. There is no study on the denazification of the French zone as a whole, there are only regional studies on the Saarland, Württemberg-Baden and the Palatinate. For a still quite accurate overview of the literature on denazification, see Cornelia Rauh-Kühne, 'Die Entnazifizierung und die deutsche Gesellschaft', Archiv für Sozialgeschichte, 35 (1995), 35-70. See also Konrad Jarausch, After Hitler. Recivilizing Germans 1945-1995 (Oxford University Press, 2006). Very recently the research has turned again to the study of denazification in Germany as a whole and the French zone in particular. See for instance the conference organized by the German Historical Institute in Paris in March 2018 titled 'La France et la dénazification de l'Allemagne après 1945' as well as the book projects by Mikkel Dack and Rebecca Boehling.

99 'Le Général de Gaulle refute les allégations mensongères sur l'administration de notre zone d'occupation', Nouvelles De France, 16 Nov. 1945. See also: MAE, AC 852/10 Allemagne, guerre. 1944-6. 
their respective occupation zones. ${ }^{100}$ Or perhaps it was due to the relative unimportance to the Allies of this rather small and rural zone in Germany's southwest. The French zone had the reputation of being a terra incognita. In 1947 a British observer noted that there was an aura of secrecy in the French zone, such that nobody even knew how many French occupiers in total actually lived on German soil - let alone former Vichy administrators. ${ }^{101}$ It is therefore no surprise that in the midst of the scandal over the Vichy administrators caused by the Parisian newspapers in the fall of 1945, the London Times acknowledged their criticism of the presence of former Vichy administrators in Germany but also stoically praised the qualities of the French occupiers: 'the military government has been recruited from some of the best of the Republic's servants, and one is impressed not only by the earnestness and enthusiasm but also by the sense of mission which inspires these men and women'. ${ }^{102}$

It is true that the presence of administrators from the resistance to some extent kept the Vichy old guard in check. Having strong personalities from the resistance in other key positions of the zone made sure the former Vichy administrators did not monopolise decision making in Germany. For example, there was Emile Laffon at the head of the military government, General Koenig at the head of the military and the governors of the Palatinate, (Boislambert), the Saar (Grandval) and Baden (Pène). Furthermore, there were many Gaullists among the younger members of the military government, such as Pierre Bolotte and Maurice Grimaud in the entourage of Laffon. Many non-commissioned officers and Gaullists saw their mission in Germany as one very much in line with their activism during the resistance, making them suspicious of the administrators from the old guard. ${ }^{103}$ The sheer presence of those Gaullists helped to contain and align the former Vichy administrators with the democratic values of the new French republic. The historian Klaus-Dietmar Henke noted a similar practice in the French denazification of the Germans: government officials with a Nazi past were installed in a position where they were dependent upon an official with anti-Nazi convictions. ${ }^{104}$ For some former Vichy officials this strategy seemed to have worked. Grimaud, for example, recalled that Sabatier had been passive:

Since he got his fingers burned [by the purge commission], he employed such a bureaucratic caution that our young team got used to ignore him and to deal straight with his more dynamic departmental heads: Raymond Schmittlein of the Public Education, Jean Moreau of the Youth or Jean Arnaud of the Information department, who were themselves happy to escape from a sterile tutelage. ${ }^{105}$

Sabatier thus retreated into safe administrative processes. 'He never took the slightest initiative', remarked Grimaud, 'he did only paperwork, controlled paperwork'. ${ }^{106}$ But Grimaud also noted that Sabatier and other former Vichy administrators had the flexibility to adapt to a new governmental situation inherited from their long career in administration, which allowed

100 See for example the classic study on denazification in the American zone, Lutz Niethammer, Die Mitläuferfabrik: Die Entnazifizierung am Beispiel Bayerns (Berlin: Dietz, 1982).

101 'The French Zone of Germany. Drawbacks of a Profitable Policy', The Manchester Guardian, 22 Dec. 1947.

102 'In the French Zone', Times London, 30 Nov. 1945.

103 See Emmanuel Droit, 'Le RPF dans les Zones Françaises d'Occupation en Allemagne (1947-1958)', in François Audigier and Frédéric Schwindt, eds., Gaullisme et Gaullistes dans la France de l'Est sous la IV République (Rennes: Presses Universitaires de Rennes, 2009), 187-201.

104 Klaus-Dietmar Henke, Politische Säuberung unter französischer Besatzung: die Entnazifizierung in WürttembergHohenzollern (Stuttgart: Deutsche Verlags-Anstalt, 1981), 49.

105 Archives Sciences Po Paris. Fonds Grimaud, GRI 1, Dossier 3, éléments biographique, Essai de C.V., 15 Aug. $1996,21$.

106 MAE AOR 14 Grimaud, Maurice. This supports F. Roy Willis thesis who doubted that the former Vichy administrators had any major influence on the policy of the French zone while he also suggested that those who had served the Vichy state had a desire for revenge, which the occupiers coming from the resistance lacked. See Frank Roy Willis, The French in Germany, 1945-49 (Stanford University Press, 1962), 149. 
them to hold onto their positions and stay in Germany, whereas many young and unconventional administrators of the Laffon circle left Germany as fast as they could. ${ }^{107}$

Jean Filippi, on the other hand, took a more active role. In addition to his above-mentioned efforts in organising the economy of the zone, he improved the denazification procedures to prevent Nazis from circumventing sanctions. Filippi, for instance, suggested to Laffon that denazification be centrally coordinated in Baden-Baden in order to remedy the uneven implementation of Laffon's denazification instructions in the different regions of the zone. ${ }^{108}$ Indeed, when, in October 1945, Governor General Schwartz of Württemberg suggested employing administrators that had been purged in the American zone so as to reinforce the administration in Freiburg, it was Filippi who intervened. ${ }^{109}$ Instead of relying on the old guard, Filippi did not shy away from demanding training courses for new, untainted, qualified employees. ${ }^{110}$ While the former Vichyssois continued to put their expertise at the service of whatever regime was willing to employ them, they had nevertheless been chastened by their Vichy experience.

\section{Conclusion}

France was in a peculiar position in the wake of the Second World War. It was the only country among the four Allies occupying Germany in 1945 that had not only been completely occupied by Nazi Germany during the war, but whose government and administration actively collaborated with the Nazis. At the time of liberation the new French state could not afford to let its tainted elite bureaucrats go. They were experienced experts in matters of administration, had benefitted from long years of training and careers in the Third French Republic and additionally had the prestige that went along with their high positions in the administration of the state. ${ }^{111}$ Charles de Gaulle stated, as early as 25 July 1944, in a speech in front of the provisional consultative assembly in Paris: 'the government has no intention to suddenly make a clean sweep of the large majority of civil servants who for the most part have tried above all to serve as best as they could the state during the terrible years of the occupation and usurpation'. ${ }^{112}$ But since, in effect, the French nation was still in a logic of 'civil war' and did not accept former Vichy officials in the same positions, those civil servants were sent to occupied Germany where they were out of the sight of the French public - and where the Germans were either too caught up with the immediate consequences of their defeat to resist their employment, or were possibly even eager to collaborate with them. In the direct aftermath of the war, new positions for former resisters as well as for former collaborators were being negotiated. While the latter could not remain in the same positions in post-war France, the expertise of former Vichy officials was urgently needed in Germany. When the French public discovered the presence of those Vichyssois in the fall of 1945 the scene of this Franco-French 'civil war' turned to French-occupied Germany, where denazification was also underway. However, the heads of the French administration composed of

\footnotetext{
107 Archives Sciences Po Paris. Fonds Grimaud, GRI 4. Alain Cances, Dans quelles conditions décidez-vous de partir pour l'Allemagne en août 1945?, no date, 6b. Bolotte, for instance, left Germany in spring 1946, having found employment at the secretary of state in Paris.

108 Reinhard Grohnert, Die Entnazifizierung in Baden, 1945-1949: Konzeptionen und Praxis der 'Epuration' am Beispiel eines Landes der französischen Besatzungszone (Stuttgart: Kohlhammer, 1991), 69-70.

109 Reinhard Grohnert, Die Entnazifizierung in Baden, 1945-1949: Konzeptionen und Praxis der 'Epuration' am Beispiel eines Landes der französischen Besatzungszone (Stuttgart: Kohlhammer, 1991), 73.

110 Reinhard Grohnert, Die Entnazifizierung in Baden, 1945-1949: Konzeptionen und Praxis der 'Epuration' am Beispiel eines Landes der französischen Besatzungszone (Stuttgart: Kohlhammer, 1991), 75.

111 On the importance of experts for Vichy France's administration and the continuous reliance on experts in the post-war administration within metropolitan France, see Robert Paxton, Vichy France: Old Guard and New Order 1940-1944 (Columbia University Press, 2001), 259-68 and 334-43.

112 Charles de Gaulle, Discours et messages. Pendant la guerre, juin 1940-janvier 1946 (Paris: Plon, 1970), 432. On de Gaulle's avoidance of an open civil war, see Olivier Wieviorka, 'Guerre civile à la française ? Le cas des années sombres (1940-1945)', Vingtième Siècle. Revue d'Histoire, 85, 1 (2005), 13-6.
} 
resisters like Laffon held onto those administrators, not wanting to put their own purge commissions - and the Fourth Republic's legitimacy - into question.

The example of the Vichyssois 'outsourced' in occupied Germany shows how Vichy-tainted administrators of the middle ranks navigated the transition between Vichy and the Fourth Republic. The historiography on the French purges mostly ends with the verdicts of the purge commissions or trials but does not consider how Vichy-tainted but purged collaborators were reintegrated in the French society in the years following the end of the German occupation. ${ }^{113}$ The flight of more or less prominent collaborators outside of France as one way to hide from persecution (before or after they received the verdict of the purge commission) has, however, gained more attention in recent years: two studies focused on the fate of escapees from Vichy France to Switzerland and to Canada. ${ }^{114}$ In this article I have shown that the temporary sidelining (mise à l'écart) of Vichy-tainted officials outside of the borders of France was also common practice for those Vichyssois within the bureaucracy who had gone through the purge commission at the end of the war without punishment, but whom the French public still considered too tainted to serve the metropole. Luc van Dongen speaks of a 'very discreet purgatory' for former supporters of the Vichy state in Switzerland, an expression that does not quite fit the Vichyssois in Germany because of the high positions they held in the French zone. ${ }^{115}$ But one can rather speak of a comfortable hibernation. Considering their long careers in the French Third Republic, their displacement was, however, still a period of penance: without the Vichy-episode, those men would have certainly reached more prestigious positions in metropolitan France's administration at the end of the war.

The 'discovery' of the Vichyssois and the subsequent scandal around the employment of Vichyssois in occupied Germany also demonstrates that former resistance fighters were divided about the employment of former members of the Vichy administration. While high-ranking members of the French administration, like Laffon and De Gaulle, accepted the presence of tainted administrators in post-war France, others fought violently against their employment, such as the head of the 'purge commission' Grumbach, or at least contested their presence, like Bolotte or Grimaud. But the latter, the young untainted administrators, were in too weak a position to intervene. The same was true for the press: in autumn 1945 one newspaper article furiously criticised the presence of the Vichy administrators in French occupied Germany. But at the article's end its author gave up and asked: 'but who would think that in order to administer Germany we would make an effort that we had been incapable of even at home in France'. ${ }^{116}$

Consequently, the scandal fizzled out, the complaisant higher-ranked resisters asserted themselves and the tainted Vichy administrators stayed. With the more radical approach towards the Vichyssois losing ground, the conflict between resisters and former Vichy administrators in the first months of the occupation around new positions and hierarchies in post-war France faded in the face of their common work in Germany for the new French state, as well as in the face of the Vichyssois' experience, flexibility and inherited prestige in their prefectural careers. In

113 See, for example, Jean-Paul Cointet, Expier Vichy: L'épuration en France (1943-1958) (Paris: Perrin, 2008) or the classic Peter Novick, The Resistance versus Vichy: The Purge of Collaborators in Liberated France (London: Chatto \& Windus, 1968). This is equally true for Fabrice Virgili, Shorn Women: Gender and Punishment in Liberation France (Oxford; New York: Berg, 2002).

114 See Luc van Dongen, Un purgatoire très discret : La transition helvétique d'anciens nazis, fascistes et collaborateurs après 1945 (Paris, Genève: Perrin; Société d'histoire de la Suisse romande, 2008) and Marc Bergère, Vichy au Canada: l'exil québécois de collaborateurs français (Rennes: Presses universitaires de Rennes, 2015). Those two examples mainly focus on cases of collaborators who escaped the purges in France at the end of the war. The Vichyssois in this article had been purged and had mostly been reintegrated into their ministries of origin in France and were only afterwards sent to Germany.

115 See the title of Luc van Dongen, Un purgatoire très discret : La transition helvétique d'anciens nazis, fascistes et collaborateurs après 1945 (Paris, Genève: Perrin; Société d'histoire de la Suisse romande, 2008).

116 'Civile ou militaire', Combat, 8 Nov. 1945. 
occupied Germany we can observe how the post-war settlement between former resisters and former collaborators was worked out. Martial Libera retrospectively named the French community in Germany a 'society of occupants'. ${ }^{117}$ Edgar Morin, an eye-witness of the French occupation in Germany, went as far as speaking of a reconciliation or coalition between resisters and former Vichy officials in the French zone. ${ }^{118}$ The newspaper Combat put this odd coalition between former resisters and former collaborators in a nutshell: 'you must get along marvellously among French and live just like a big family. . . . Because, of course, everyone knows that the French are only divided within the borders of their country, and once they are abroad, they stop eating each other's throats. ${ }^{119}$

Thus, the French community of occupants represents a magnifying glass for the settlement of the Franco-French 'civil war'. During their temporary mise à l'écart, the tainted Vichy administrators in Germany could rely on their long years of experience in matters of administration and their acquired rank in the hierarchy that had endured the four years of Vichy rule to secure their positions after the war. Their stay in occupied Germany was a mere temporary hideout as well as a probation period before they could safely return to France having proven their support for the new French Republic. The former Vichy administrators remained in Germany until they found new employment in either another administration or in the private sector in the late 1940s or early 1950s. In particular, the administrators in the higher positions were, after their short interlude in occupied Germany, able to advance their careers and to secure positions in the prestigious international circles of the United Nations (Périer de Féral) or the French high administration in the council of state (Sabatier) or the senate (Filippi). Despite their implication with the Vichy regime, those men returned to metropolitan France and continued to influence French post-war politics well beyond the Second World War.

The Vichy past of those administrators was dug up periodically during the late 1940s and early 1950 s by left-wing newspapers whose editors remembered the faces of the former Vichy administrators - but with practically no impact on personnel decisions. The French repressed the memory of the Franco-French 'civil war' from the 1950s, as Henry Rousso described in his pioneering study Vichy Syndrome. ${ }^{120}$ This post-war settlement lasted until the early 1980s. Up to then none of these thirteen Vichyssois sent to Germany after the war had thus far been tried for their complicity with the Vichy state and the crimes that this state committed under the auspices and at the request of the German occupiers. In the 1980s and 1990s, however, a new French generation who had not experienced the Nazi occupation led a proxy trial, the famous Papon trial. ${ }^{121}$ Maurice Papon, secretary general of Bordeaux from 1942 to 1944, was accused along with his mentor and immediate superior Maurice Sabatier, a central figure in my article, who was regional prefect of the Gironde and long-time head of the general directorate of administrative affairs in French-occupied Germany. In 1981 Maurice Papon was budget minister when the French satirical weekly Le Canard Enchaîné published an article about Papon's implication in the deportation of over 16,000 Jews from Bordeaux to the Nazi death camps. However, this article in Le Canard Enchaînée did not fizzle out like the ones cited above. Instead, it cracked the post-war compromise and triggered one of the longest trials in French history: in 1998 Maurice Papon was convicted of 'crimes against humanity', more than fifteen years after the initial charge, and was

\footnotetext{
117 See Martial Libera, Un rêve de puissance : La France et le contrôle de l'économie allemande (1942-1949) (Bruxelles: Peter Lang, 2012), 315.

118 See Edgar Morin, Allemagne notre souci (Paris: Hier et aujourd'hui, 1947), 35.

119 SHD 4 Q 22, 'En Allemagne occupée... Baden-Baden le dernier salon où l'on danse...', L'Alsace, 21 Sept. 1945.

120 Henry Rousso, The Vichy Syndrome: History and Memory in France since 1944 (Harvard University Press, 1994).

121 See Richard Joseph Golsan, The Papon Affair: Memory and Justice on Trial (London: Routledge, 2000). For the generational change in the memory of the German occupation and the Holocaust see for example: István Deák, 'Introduction', in István Deák, Jan T. Gross and Tony Judt, eds., The Politics of Retribution in Europe: World War II and its Aftermath (Princeton University Press, 2009), 12 and Annette Wieviorka, The Era of the Witness (Cornell University Press, 2006).
} 
sentenced to ten years of imprisonment. It was, however, Maurice Sabatier's spectre that hung over this entire trial.

In 1981, when the 'Papon affair' started, the by then eighty-four-year-old honorary counsellor of state, Sabatier, rushed to his protégé's defence. He declared that he accepted 'the full responsibility for the anti-Jewish repression in the jurisdiction of his prefecture'. ${ }^{122}$ Their close relationship throughout the Vichy period thus seemed to have led Sabatier to cover for Papon in 1981. Consequently, the examining magistrate indicted Sabatier as well. But Sabatier died in 1989 before the trial began. Maurice Sabatier was therefore the 'big absentee' in the Papon trial. His 'non-inculpation remains the original sin' of the Papon trial, commented the journalist and coauthor of a ground-breaking piece on the memory of Vichy, Eric Conan, when the trial finally started. ${ }^{123}$ It was Sabatier who should have been put on trial; Papon was merely his replacement, Conan argued. Sabatier's spectre haunted the assize court to the extent that its president, JeanLouis Castagnède, mistakenly addressed Maurice Papon as Maurice Sabatier in a memorable Freudian slip: 'could you please answer the question, Monsieur Sabatier?'124

More than thirty-five years after the end of the Second World War, Maurice Sabatier thus almost became the first and only of the thirteen Vichyssois in occupied Germany to be tried for his implication in the crimes committed during the Vichy regime. Because of his death this trial never occurred. The Papon trial replaced what should have been the Sabatier trial, but it destroyed the post-war settlement and laid bare the struggle over French identity after the German occupation that had started in France during the war, continued in French occupied Germany and finally returned to France, where it was at last brought to trial.

Cite this article: Wambach, J. 2018. Vichy in Baden-Baden - The Personnel of the French Occupation in Germany after 1945. Contemporary European History 28, 319-341. doi: 10.1017/S0960777318000462

122 Quoted from Eric Conan, 'Le Grand Absent', L'Express, 20 Nov. 1997. http://www.lexpress.fr/actualite/politique/legrand-absent_494911.html (Last visited 11 Jul. 2018).

123 Eric Conan and Henry Rousso, Vichy: An Ever-Present Past (Hanover: University Press of New England 1998).

124 Quoted from Eric Conan, 'Le grand absent', L'Express, 20 Nov. 1997. http://www.lexpress.fr/actualite/politique/le-grandabsent_494911.html (Last visited 11 Jul. 2018). 